\title{
TECHNOLOGIES FOR SUSTAINABLE RURAL LIVELIHOOD IN NORTH EAST INDIA
}

\author{
Merry Borgohain \\ Research Scholar, (M.Phil), Dibrugarh University, \\ Department of Commerce, Assam, India.
}

\begin{abstract}
The concept of 'sustainable livelihoods' is of immense significance in the context of social development. This paper outlines a framework for the impact of technology for uplifting the rural livelihood in North East India. This study has been conducted to understand the present scenario of rural livelihood in North East India. The framework shows the available technologies for rural development, the extent of their use and the outcome as a whole. North East India is a region rich in bio-diversity, fertile soil, varied agro-ecology, immense water resources, human resources which are potential sources to develop the agricultural as well as economy of the region. However, due to lack of proper strategies for maintaining the natural resources, less co-ordination in programme implementation, lack of proper communication facilities, and poor infrastructural facilities the region has been lagging behind towards development. Scientific approaches, studies and innovations are highly essential to overcome the constraints that are being faced today in the rural areas. India being a very large country, with diverse geographical and ecological conditions, and varied socio cultural background of the rural population, a uniform prescription or model would be inappropriate for application in all the regions. As North East is a less developed region in India and a huge number of rural population are involved in agriculture which contributes greatly towards the Indian economy as a whole so, appropriate technology should be adopted to enhance the livelihood of the rural people.
\end{abstract}

Key words: Sustainable livelihood, rural, North east, technologies, development.

Cite this Article: Merry Borgohain, Technologies for Sustainable Rural Livelihood in North East India, International Journal of Management, 11(12), 2020, pp 1727-1732. http://iaeme.com/Home/issue/IJM?Volume $=11 \&$ Issue $=12$ 


\section{INTRODUCTION}

\subsection{Sustainable Rural Livelihood}

A rural livelihood is defined as "the capabilities, assets and activities that rural people require for a means of living." Here the available resources are converted to useful means through different methods which results in the creation of sources of living for the rural population. Most of the rural people are peasants. They are basically engaged in farming activities which tend to be dependent on family labour and also use low capital.

Indian economy has consistently tried to include the rural population which is basically engaged in agriculture and is its main economic activity. However poverty persists among this population due to limited access to productive resources, technology, lack of adequate finance and also exposure to flood, drought and other such natural calamities. Low literacy rate and lack of skills trap people in poverty which prevents them from engaging in newer and advanced economic activities. The concept of sustainable rural livelihood emerged in order to eliminate the problem of rural poverty. In the words of Chambers and Conway (1992), "A livelihood is sustainable when it can cope with and recover from stresses and shocks maintain or enhance its capabilities and assets, while not undermining the natural resource base." The word sustainable has been used to provide development in rural livelihood to benefit the present generation without harming nature and preserving it for the future generation.

\section{IMPORTANCE OF THE STUDY}

- As in North East India more than $85 \%$ population belongs to the rural area, so it has become very essential to give utmost importance to improve their livelihood.

- Being an agriculture based economy, the influence of technology is vital in the region for its development.

\section{OBJECTIVES}

- To understand the present scenario of rural livelihood in North East India.

- To study the available technology and their impact on the livelihood of the rural population.

\section{METHODOLOGY}

The study is based on secondary information taken from different research papers, articles and websites on the internet.

\section{PROBLEMS OF LIVELIHOOD}

In North East India, most of the rural people generate their income from agriculture, and spend about $75 \%-80 \%$ of their earnings on food. This is due to absence of employment opportunities in industrial and service sectors. Agriculture is the major source of livelihood but most of the illiterate farmers have not been successful in cultivating their land economically. They have been treating agriculture as a family tradition, followed age old practices and adopted new changes only after observing the success of their neighbors. As the chances of crop failure on these lands is very high, the farmers generally do not invest in external inputs like improved seeds, fertilizers and plant protection measures and end up with poor crop yields, even during normal years.

The Government has reserved about $10 \%$ of the total land in each village for livestock grazing. The ownership of this land is with the Village Panchayat. The Panchayat has no control over the use. This has resulted in over-exploitation and degradation of the pastures. Thus, in spite of land scarcity, over $50 \%$ of the total land remains either idle or under-utilized. 
Management of these wastelands to improve the productivity can revive the supply of fodder and fuel, facilitate the percolation of rainwater and improve agricultural production.

Therefore, it is necessary to promote suitable rural technologies which can enable the local communities to enhance their efficiency and earnings. With the improvement in agricultural production, various opportunities can emerge in the agri-business and non-farm sectors in the future which will lead to improve rural livelihood.

\section{TECHNOLOGIES FOR SUSTAINABLE RURAL LIVELIHOOD}

There are many Governments and Non-Government Agencies engaged in providing sustainable livelihood to the rural poor. Over the years, a large number of activities have been identified both in agricultural and industrial sector. The technologies can help the farmers to earn adequate income to eradicate poverty. Important technologies for providing sustainable livelihood in rural areas are presented below:

- Water Resource Development: As only a minimum percentage of rain water is effectively used and over $70 \%$ of the agriculture is dependent on rainfall, there is good scope to promote water resources development. Efficient rainwater harvesting along with promotion of sustainable agricultural practices, can increase the crop production that will generate employment throughout the year. Managing the release and distribution of water is critical for maximising production.

- In rain-fed areas, the construction of dams is vital. Choosing the right location for such water-harvesting structures can be greatly facilitated by using satellite remote sensing data. Where irrigation is from wells, the simple technology for the pump to be automatically switched on when power is available.

- Computer kiosk and Mobile Phones: Information related to transportation, commodity prices, weather, etc., are important for the farmer. Technology can now provide this easily and instantaneously either at a village computer kiosk or on a mobile handset. Transactions, including purchase of agricultural raw materials, but also other goods and services, can also be handled on such kiosks or on a mobile phone.

- Cold storage: Cold storage and cold-chains for transportation to market is of great importance for many agricultural products particularly, fruits and vegetables that are perishable.

- Purified water: Water is responsible for a majority of the health problems in rural areas. While many technologies exist for water-purification, there is need for developing context-specific technologies at low-cost, reliable and not powerdependent for providing safe drinking water.

- Household technology: Fuel for cooking has drawn attention. Efficient smoke-less chulas; briquettes, solar-cookers, the cost-efficient technologies that fit the sociocultural milieu are yet awaited. The government has also taken initiative to provide less power consuming LED bulbs per electricity connection.

- Vermi-composting: (The use of earthworms for composting organic residue): It is a method by which organic farm waste is converted to nutrient-rich fertilizer in a small shed so that it can be applied to crop fields and horticultural establishments. It enables the local farmers to develop skills to harvest this product which can easily become the backbone of the sustainable organic farming of the villagers and the country at large.

- Housing: Several technologies have been developed in the area of low cost building materials, designs and construction techniques. 
- Biotechnology: In the field of biotechnology, developments relating to biofertilizers, aquaculture, biomass production through tissue culture techniques, embryo-transfer technology to upgrade cattle, herds, etc. have enormous, potential for employment generation and increasing efficiency and productivity for activities in daily life in rural areas.

- Information Technology: Use of information technology in sectors like agriculture, irrigation, energy, health; family planning, education, employment and transportation is vital for bringing about a major transformation in the rural sector. Information related to local resources, skills and need is important to carry out effective decentralized planning.

- Space Technology: There are a wide range of applications of remote sensing technology in areas of disaster warning for coastal inland fisheries, minor irrigation, water targeting for drinking water, wasteland identification, etc.

- Livestock Development: Dairy husbandry was considered as the most powerful tool, as most of the cattle and buffaloes in the country in spite of being low productive, could still be used as breeding stock to produce superior quality progeny. Most of the rural folk own such low productive animals. Providing doorto-door breeding services helped the farmers to produce superior quality milch animals from low producing cattle and buffaloes.

- Technologies for Tree-based Farming: In rain fed areas, where there are many constraints for increasing the crop yields, tree-based farming can be a boon as trees have better ability to tolerate erratic weather conditions. Depending on the soil fertility and water availability, different tree species can be grown. Various technologies are used in the production of rubber, paper, timber etc. some other technologies that are used in tree based farming are:

- Sericulture: As mulberry plants can be established as intercrop in fruit orchards, with the new technologies sericulture has good potential to provide substantial income within a short gestation of 4-6 months.

- Food Processing: It is estimated that about $20-30 \%$ of the agricultural products, particularly fruits and vegetables, are lost due to poor handling. Exploitation by the traders further affects the profit. Hence, processing of horticultural produce with the new technologies is not only essential but also provides an opportunity to earn additional income.

\section{DISCUSSION}

- In North East India, most of the rural people generate their income from agriculture, and spend about $75 \%-80 \%$ of their earnings on food. The main reason behind this is the absence of employment opportunities in industrial and service sectors. With that agriculture is the major source of livelihood but most of the illiterate farmers have not been successful in cultivating their land economically. People in the rural are not fond of higher studies or the required studies for better cultivation. And with that they are adopting the new method of cultivation only after observing the success of neighbours.

- In order to reduce this kind of problems, that has greater impact on the livelihood of the rural people, government should take initiative to educate the rural people. Government should go for awareness camps to make the rural people aware about various technologies, schemes available to them. Government should focus mainly on the youths and make them understand 
about the scientific way of cultivation for better production which will enhance their livelihood.

- Livelihood of rural people are increasing only because that any member of the families are working in any industry in the urban area. There is lack of government initiative on industrialization of the rural areas, which is a major constraint on the development of rural livelihood. Instead of transferring materials to urban, paying transaction cost, villagers can go for small industries to generate income, with the help of schemes and technologies provided by the government. It will increase the livelihood of rural people by generating employment.

- Technology and innovation in the rural areas of North East India are mostly based on the agricultural sector. China has developed its economy only by use of technology in agricultural sector after 1990. So it is necessary for the region as well as the country to develop it by enhancing the livelihood of rural people by use of various technologies.

- There are a few technologies in North east India. Government of India as well as the state governments started providing technologies for the development of livelihood of rural people such as Water Resource Development, Computer kiosk and Mobile Phones, Cold storage, Purified water, Household technology, Vermi-composting, Housing, Biotechnology, Information Technology, Space Technology, Technologies for Tree-based Farming, Livestock Development etc. which are yet to be properly utilised. Due to lack of awareness about the technologies and also about less knowledge and skills the rural population is still lagging behind.

- There should be improvement and standardization of production techniques. Some economic packages can be introduced in the form of integrated farming systems by combining crop cultivation with livestock, fishery, etc. The facilities of cold storage, processing and marketing are particularly deficient for perishable goods which are needed to be scientifically developed.

- Entrepreneurship Development Programmes are required to be conducted to motivate them to be entrepreneurs by availing financial assistance from the various schemes provided by the government.

\section{CONCLUSION}

North East India is a region of mega bio-diversity, fertile soil, varied agro-ecology including immense water resources, human resources which are potential sources of agricultural as well as economic development of the region. In spite of such boons, due to lack of proper strategies for developing the natural resources, absence of co-ordination in programme implementation, weak geographical links and poor infrastructural facilities the region has stayed far back on the developmental pathways. Scientific approaches, studies and innovations are absolutely essential to solve the urgent problems that are being faced today in the rural areas. India being a very large country, with diverse geographical and ecological conditions, and varied socio cultural background of the rural population, a uniform prescription or model would be inappropriate for application in all the regions. As North East is a less developed region in India and a huge number of rural population are involved in agriculture which contributes greatly towards the Indian economy as a whole so, proper technology should be adopted to provide adequate rural livelihood in the region. 


\section{REFERENCES}

[1] Role of Science and Technology In Making Rural India Shine by Nisheeth Rai \& Vijay Kumar,serialsjournals.com

[2] Sustainable Rural Livelihoods: A Framework for Analysis by Institute of development Studies, http://www.ids.ac.uk

[3] Technologies For Providing Sustainable Rural Livelihood By Dr. N.G. Hegde, www.baif.org.in

[4] http://india.ashoka.org/changing0-face-north-east-india

[5] http.//googleweblight.com/i?u+http://www.asthabharati.org/Dia_Jan\%252009/the\%2520N.E. $\% 2520$ ind.htm\&grqid $=$ Lah-A8TJ\&hl=en $=\mathrm{IN}$

[6] http://indiamicrofinance.com/agricultural-in-north-east-india.html/amp

[7] http://economictimes.indiatimes.com/articleshow/2859967.cms?utm_source=contentofinterest \&utm_medium $=$ text\&utm_campaign $=$ cppst 